\title{
Pengaruh Penguasaan Kosakata dan Kemampuan Berpikir Kreatif terhadap Kemampuan Menulis Teks Naratif Bahasa Indonesia
}

\author{
Feniliya \\ Universitas Indraprasta PGRI \\ Jalan Nangka No. 58 C/TB. Simatupang, Tanjung Barat, Jakarta Selatan 12530 \\ she_feni@yahoo.com
}

\begin{abstract}
The purpose of this study was to find out 1) The effect of vocabulary mastery and the ability to think creatively on the ability to write Indonesian narrative texts in Private Middle School students in Depok. 2) Effect of vocabulary mastery on the ability to write Indonesian narrative texts in Private Middle School students in Depok. 3) Effect of creative thinking skills on the ability to write Indonesian narrative texts in Private Middle School students in Depok. The population is class VIII Private SMP in Depok City with a sample size of 50 students. Data collection is carried out by means of questionnaires and questionnaires. Data analysis used simple linear regression and multiple linear regression. The results of testing the hypothesis obtained conclusions as follows: 1) There is a significant effect of mastery of vocabulary and the ability to think creatively together on the ability to write narrative texts of Private Middle School students in Depok City, based on the Sig. 0,000 $<0,05.2)$ There is a significant effect of vocabulary mastery on the ability to write narrative texts of Private Middle School students in Depok City, based on Sig. 0.006>0.05. 3) There is no significant influence on the ability to think creatively towards the ability to write narrative texts of Private Middle School students in Depok City, based on the Sig. 0.098> 0.05. The results of this study are useful for improving the ability to write narrative texts at the junior secondary level.
\end{abstract}

Keywords: vocabulary mastery, ability to think creatively, narrative texts.

\begin{abstract}
Abstrak
Tujuan penelitian ini adalah untuk mengetahui 1) Pengaruh penguasaan kosakata dan kemampuan berpikir kreatif terhadap kemampuan menulis teks naratif Bahasa Indonesia siswa SMP Swasta di Depok. 2) Pengaruh penguasaan kosakata terhadap kemampuan menulis teks naratif Bahasa Indonesia siswa SMP Swasta di Depok. 3) Pengaruh kemampuan berpikir kreatif terhadap kemampuan menulis teks naratif Bahasa Indonesia siswa SMP Swasta di Depok. Populasi adalah siswa kelas VIII SMP Swasta di Kota Depok dengan besar sampel sebanyak 50 siswa. Pengumpulan data dilaksanakan dengan cara penyebaran angket dan kuesioner. Analisis data menggunakan regresi linear sederhana dan regresi linear ganda. Hasil pengujian hipotesis diperoleh kesimpulan sebagai berikut: 1) Terdapat pengaruh yang signifikan penguasaan kosakata dan kemampuan berpikir kreatif secara bersama-sama terhadap kemampuan menulis teks naratif siswa SMP Swasta di Kota Depok, berdasarkan nilai Sig. $0,000<0,05$. 2) Terdapat pengaruh yang signifikan penguasaan kosakata terhadap kemampuan menulis teks naratif siswa SMP Swasta di Kota Depok, berdasarkan Sig. 0,006>0,05. 3) Tidak terdapat pengaruh yang signifikan kemampuan berpikir kreatif terhadap kemampuan menulis teks naratif siswa SMP Swasta di Kota Depok, berdasarkan nilai Sig. $0,098>0,05$. Hasil penelitian ini berguna untuk meningkatkan kemampuan menulis teks naratif di tingkat SMP.
\end{abstract}

Kata Kunci: penguasaan kosakata, kemampuan berpikir kreatif, kemampuan menulis teks naratif. 


\section{PENDAHULUAN}

Pendidikan merupakan hal yang sangat penting bagi pembentukan sumber daya manusia yang memiliki kompetensi di berbagai bidang tertentu, baik di bidang ekonomi, sosial, budaya, maupun pertahanan dan keamanan. Melalui pendidikan, sumber daya manusia dipersiapkan dan dibentuk untuk memiliki seperangkat pengetahuan, pemahaman, kemampuan, dan keterampilan. Dengan pengetahuan, pemahaman, kemampuan, dan keterampilan, sumber daya manusia dapat mengembangkan kreativitasnya dan memecahkan persoalan bangsa dan masyarakat guna menyejahterakannya. Hal ini menunjukkan bahwa peran pendidikan sangatlah penting.

Kemampuan berpikir juga memiliki peranan penting dalam proses pendidikan. Melalui berpikir, guru tidak hanya sekadar melakukan transfer pengetahuan, namun menjadikan kegiatan pembelajaran menjadi lebih berkualitas dan bermakna. Hartati (2002: 79) menyatakan bahwa salah satu tujuan pendidikan adalah melatih apa yang dimiliki siswa untuk berpikir kreatif. Kemampuan ini sangatlah penting dimiliki siswa, sebab pembelajaran yang melibatkan kemampuan berpikir akan menjadikan pembelajaran menjadi lebih bermakna, sehingga siswa memperoleh hasil yang maksimal dari kegiatan pembelajaran yang dilakukan. Bahasa Indonesia merupakan salah satu ilmu penting yang diajarkan di sekolah, dikarenakan segala jenis aktivitas dalam kehidupan sehari-hari selalu memerlukan cara-cara penyelesaian yang menuntut seseorang untuk menguasai bahasa Indonesia. Bahasa Indonesia selalu berkembang sesuai dengan dinamika perkembangan zaman, baik kandungan materi maupun penggunaannya.

Seseorang dikatakan terampil berbahasa Indonesia apabila orang tersebut telah menguasai sistem bahasa Indonesia secara keseluruhan, yaitu mencakup keempat hal tersebut. Keterampilan berbahasa berbeda pada setiap orang. Berdasarkan empat keterampilan berbahasa, keterampilan menulislah yang paling sulit dikuasai siswa karena menuntut penguasaan keterampilan berbahasa lainnya dan juga proses kognitif siswa. Selain itu, keterampilan menulis tidak akan datang dengan sendirinya melainkan harus dilatih dan dikembangkan sejak dini. Pendapat tersebut sejalan dengan yang diungkapkan Cahyani dan Hodijah dalam Alwasilah (2007:2) bahwa menulis merupakan keterampilan yang rumit karena menulis bukanlah sekadar menyalin kata-kata dan kalimat-kalimat, melainkan juga mengembangkan dan mengungkapkan pikiran-pikiran dalam suatu tulisan yang teratur. Selain itu, kosakata baku yang dimiliki siswa juga sedikit sekali. Siswa lebih banyak memiliki kosakata yang biasa digunakan dalam kehidupan sehari-hari, dimana kata-kata tersebut sudah tercampur dengan bahasa daerah masing-masing. Karena sedikitnya kosakata yang dimiliki, sehingga karangan atau teks yang dibuat siswa berkesan monoton.

Siswa kurang mampu dalam mengungkapkan gagasan atau idenya secara lisan maupun tertulis, disebabkan oleh kurangnya pengalaman untuk memahami lambang dan konsep, termasuk di dalamnya penguasaan kosakata yang baik. Penguasaan kosakata pada dasarnya memberi pengaruh terhadap kualitas penggunaan bahasa seseorang. Aspek kosakata berarti penguasaan bahasa yang baik menjadi cermin penguasaan kosakata yang memadai. Penggunaan kosakata

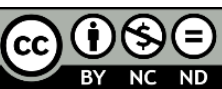

Creative Commons Attribution-NonCommercial-NoDerivatives 4.0 International License 
yang kurang baik biasanya terjadi akibat penguasaan kosakata yang kurang baik. Pustejovsky dalam Fahrudin dan Jamaris (2005:12) mengemukakan bahwa kapasitas bahasa seseorang merupakan refleksi dari kemampuannya untuk menggolongkan dan menunjukkan makna kata tertentu.

Menulis merupakan hal yang penting dalam mengembangkan kemampuan berpikir siswa dalam belajar. Menulis merupakan kemampuan tingkat tinggi dalam berbahasa, karena menulis bukan hanya menuntut kemampuan dalam berbahasa tetapi juga menuntut kecakapan dalam berpikir secara sistematis, kreatif, dan kritis. Tarigan (2008:22) menyatakan bahwa belajar menulis adalah belajar berpikir mendalam dengan cara menemukan pengalaman, penyusunan urutan pengalaman, dan ketepatan pemilihan kata. Dengan kata lain kemampuan menulis tidak dapat lepas dari kemampuan baik berpikir kreatif maupun berpikir kritis siswa.

\section{METODE}

Metode yang digunakan dalam penelitian ini adalah metode survey dengan teknik korelasional. Artinya data dijaring dengan bantuan kuesioner. Dalam penelitian ini instrumen untuk mengangkat data ketiga variabel yang diteliti menggunakan bantuan kuesioner. Menurut Kerlinger yang dikutip oleh Setiaji (2004:49) menyatakan bahwa:

"Penelitian survey adalah penelitian yang dilakukan pada suatu populasi dimana data yang dipelajari adalah data dari sampel yang diambil dari populasi tersebut, sehingga ditemukan kejadian-kejadian relatif, distribusi, dan hubungan antar variabel sosiologis dan psikologis. Penelitian survey biasanya dilakukan untuk mengambil suatu generalisasi yang dilakukan bisa lebih akurat bila digunakan sampel yang representatif'.

Variabel penelitian ini yaitu variabel terikat (dependen variable) adalah kemampuan menulis teks naratif $(\mathrm{Y})$ dan variabel bebas (Independent variable) adalah penguasaan kosakata $\left(\mathrm{X}_{1}\right)$, dan kemampuan berpikir kreatif $\left(\mathrm{X}_{2}\right)$. Menurut kerangka berpikir dan hipotesis penelitian diduga antara variabel bebas dan variabel terikat tersebut ada hubungan sebab akibat dan saling mengadakan perubahan. Untuk itu maka teknik analisis pembuktian hipotesis tersebut digunakan teknik korelasional. Adapun model konstelasi hubungan antar variabel dalam penelitian ini adalah sebagai berikut:

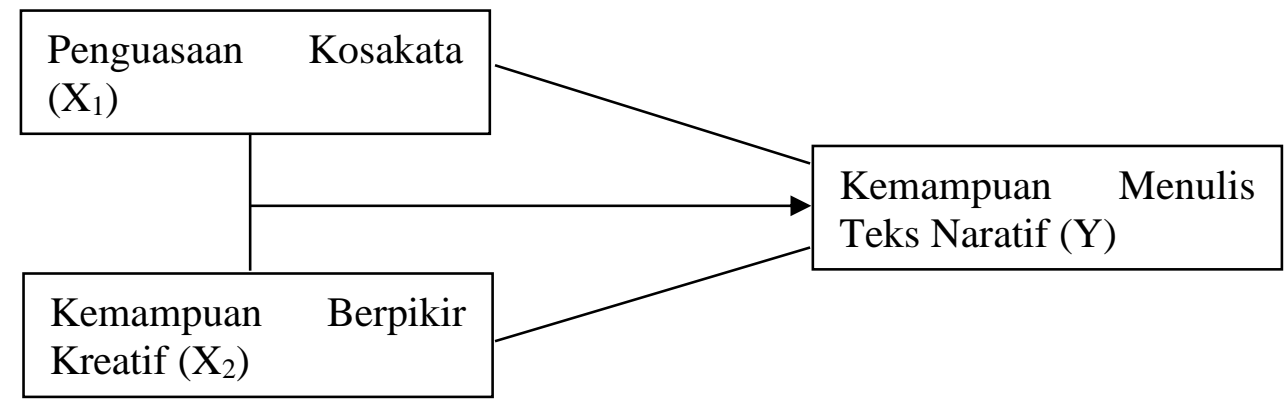


Menurut Sugiyono (2002:57), populasi adalah wilayah generalisasi yang terdiri dari objek atau subjek yang menjadi kuantitas dan karakteristik tertentu. Populasi pada penelitian ini adalah siswa SMP Budi Cendekia Islamic School, SMP Bina Insan Kamil, dan SMP Yaspen Tugu Ibu 1 yang terletak di wilayah kota Depok. Berikut tabel populasi pada penelitian ini:

Tabel 1. Jumlah Populasi Penelitian Siswa SMP Swasta di Wilayah Kota Depok

\begin{tabular}{lll}
\hline No. & Nama Sekolah & Jumlah Populasi \\
\hline 1. & SMP Budi Cendekia Islamic School & 207 \\
2. & SMP Bina Insan Kamil & 100 \\
3. & SMP Yaspen Tugu Ibu 1 & 173 \\
Jumlah Siswa & $\mathbf{4 8 0}$
\end{tabular}

Menurut Arikunto (2006:131) "sampel adalah bagian dari populasi (sebagian atau wakil populasi yang diteliti)". Sampel merupakan sumber data dan dapat mewakili seluruh populasi. Dari jumlah populasi yang telah ditetapkan diambil sampel Random Sampling (sampling acak sederhana), pemilihan rombongan belajar (kelas) dari sekolah yang terpilih. Pada penelitian ini, responden yang dipilih yaitu siswa kelas VIII ketiga SMP tersebut.

Menurut Roscoe dalam Sugiyono (2006:101), mengatakan bahwa bila dalam penelitian akan melakukan analisis multivariate (uji korelasi atau regresi ganda), maka jumlah sampel minimal adalah 10 kali jumlah variabel yang akan di teliti (minimal 48 orang sampel).

Dari populasi terjangkau diatas, diambil secara random sampling dan dibulatkan sebanyak 50 sebagai sampel penelitian. Penetapan 50 orang siswa sebagai responden/sampel penelitian ini menggunakan two-stage-randomsampling, yaitu teknik pengambilan sampel dari semua anggota populasi dilakukan secara acak tanpa memperhatikan strata yang ada dalam populasi tersebut.

\section{HASIL DAN PEMBAHASAN}

\section{Hasil \\ Deskripsi Data}

Tingkat penguasaan kosakata dari responden memiliki rata-rata 65,14 dengan simpangan baku 11,949; median 70,00; skor minimum 37; dan skor maksimum 83. Angka simpangan baku sebesar 11,949 atau sama dengan 18,34\% dari rata-rata menunjukkan perbedaan jawaban antar responden atas butir-butir soal yang ada termasuk rendah. Hal ini menunjukkan bahwa tingkat penguasaan kosakata dari responden tidak banyak beragam. Dari deskripsi tersebut juga dapat dilihat bahwa antara nilai rata-rata dan median tidak berbeda terlalu jauh, yaitu 65,14 dan 70,00. Hal ini menunjukkan bahwa data tingkat penguasaan kosakata pada penelitian ini cukup representative, sedangkan tingkat penguasaan kosakata yang berada di atas rata-rata lebih banyak dibanding yang berada di bawah ratarata, hal ini menunjukkan bahwa siswa yang mempunyai tingkat penguasaan 
kosakata yang tinggi lebih banyak dibanding yang rendah.

Tingkat kemampuan berpikir kreatif dari responden memiliki rata-rata 73,96 dengan simpangan baku 10,467; median 74,00; skor minimum 52 dan skor maksimum 99. Angka simpangan baku sebesar 10,467 atau sama dengan $14,15 \%$ dari rata-rata menunjukkan perbedaan tingkat kemampuan berpikir kreatif termasuk rendah. Hal ini menunjukkan bahwa kemampuan berpikir kreatif dari responden tidak banyak beragam. Dari deskripsi tersebut juga dapat dilihat bahwa nilai ratarata dan median hampir sama, yaitu 73,96 dan 74,00. Hal ini menunjukkan bahwa data kemampuan berpikir kreatif pada penelitian ini cukup representatif, sedangkan kemampuan berpikir kreatif yang berada di atas rata-rata lebih banyak dibanding yang berada di bawah rata-rata menunjukkan bahwa siswa mempunyai kemampuan berpikir kreatif lebih banyak dibanding yang rendah.

Data kemampuan menulis teks naratif yang diperoleh dari para responden mempunyai rata-rata 75,58; simpangan baku 10,441; median 76,50; skor minimum 60 dan skor maksimum 95. Hal ini menunjukkan bahwa rata-rata kemampuan menulis teks naratif dari responden cukup tinggi. Skor simpangan baku 10,441 atau sama dengan $13,81 \%$ dari rata-rata, menunjukkan perbedaan tingkat kemampuan menulis teks naratif termasuk rendah. Hal ini menunjukkan bahwa kemampuan menulis teks naratif dari responden tidak banyak beragam. Dari deskripsi tersebut juga dapat dilihat bahwa nilai rata-rata dan median hampir sama yaitu 75,58 dan 76,50. Hal ini menunjukkan bahwa data kemampuan menulis teks naratif pada penelitian ini cukup representatif. Sedangkan kemampuan menulis teks naratif yang berada di atas rata-rata lebih banyak dibanding yang berada di bawah rata-rata menunjukkan bahwa siswa mempunyai kemampuan menulis teks naratif lebih banyak dibanding yang rendah.

\section{Analisis Persyaratan Data}

Pada analisis persyaratan data terlihat bahwa nilai pada kolom Sig. pada metode Kolmogorof-Smirnov untuk semua sampel lebih besar dari 0.05 sehingga $\mathrm{H}_{0}$ diterima, dengan kata lain bahwa data dari semua sampel pada penelitian ini berdistribusi normal.Untuk nilai pada kolom Sig. baris Deviation from Linearity adalah 0,121 lebih besar dari 0,05; sehingga $\mathrm{H}_{0}$ diterima. Dengan kata lain bahwa garis regresi pengaruh variabel $\mathrm{X}_{1}$ terhadap variabel $\mathrm{Y}$ tersebut adalah linier.

Nilai pada kolom Sig. baris Deviation from Linearity adalah 0,546 lebih besar dari 0,05 , sehingga $\mathrm{H}_{0}$ diterima. Dengan kata lain bahwa garis regresi pengaruh variabel $\mathrm{X}_{2}$ terhadap variabel $\mathrm{Y}$ tersebut adalah linier.

Pengaruh Penguasaan Kosakata $\left(X_{1}\right)$ dan Kemampuan Berpikir Kreatif $\left(X_{2}\right)$ Secara Bersama-sama terhadap Kemampuan Menulis Teks Naratif Bahasa Indonesia $(Y)$

Terbukti bahwa niali Sig. $=0,000$ dan $F_{\text {hitung }}=14,852$. Sedangkan $F_{\text {tabel }}=$ 2,80. Karena nilai Sig. $<0,05$ dan $F_{\text {hitung }}>F_{\text {tabel }}$ maka $\mathrm{H}_{0}$ ditolak. Berarti bahwa terdapat pengaruh yang signifikan variabel bebas penguasaan kosakata $\left(\mathrm{X}_{1}\right)$ dan kemampuan berpikir kreatif $\left(\mathrm{X}_{2}\right)$ secara bersama-sama terhadap kemampuan menulis teks naratif $(\mathrm{Y})$. 
Pengaruh Penguasaan Kosakata $\left(X_{1}\right)$ terhadap Kemampuan Menulis Teks Naratif Bahasa Indonesia (Y)

Terbukti bahwa nilai Sig. $=0,006$ dan $t_{\text {hitung }}=2,888$; sedangkan $t_{\text {tabel }}=1,684$. Karena nilai Sig. $<0,05$ dan $\mathrm{t}_{\text {hitung }}>\mathrm{t}_{\text {tabel }}$ maka $\mathrm{H}_{0}$ ditolak. Artinya terdapat pengaruh yang signifikan variabel bebas $\mathrm{X}_{1}$ (Penguasaan Kosakata) terhadap variabel terikat Y (Kemampuan Menulis Teks Naratif).

\section{Pengaruh Kemampuan Berpikir Kreatif $\left(\mathrm{X}_{2}\right)$ terhadap Kemampuan Menulis Teks Naratif Bahasa Indonesia (Y)}

Terbukti bahwa nilai Sig. $=0,098$ dan $\mathrm{t}_{\text {hitung }}=1,690$; sedangkan $\mathrm{t}_{\text {tabel }}=1,684$. Karena nilai Sig. $>0,05$ dan $t_{\text {hitung }}>t_{\text {tabel }}$ maka $\mathrm{H}_{0}$ diterima. Artinya tidak terdapat pengaruh yang signifikan variabel bebas $\mathrm{X}_{2}$ (Kemampuan Berpikir Kreatif) terhadap variabel terikat $\mathrm{Y}$ (Kemampuan Menulis Teks Naratif).

\section{Pembahasan}

Pengaruh Penguasaan Kosakata $\left(X_{1}\right)$ dan Kemampuan Berpikir Kreatif $\left(X_{2}\right)$ Secara Bersama-sama terhadap Kemampuan Menulis Teks Naratif Bahasa Indonesia (Y)

Dari deskripsi data setelah dilakukan analisis korelasi diperoleh koefisien korelasi sebesar 0,622 dan koefisien determinasi sebesar 38,7 setelah dilakukan pengujian dengan program SPSS terbukti bahwa koefisien korelasi tersebut signifikan. Hal ini berarti bahwa terdapat pengaruh variabel bebas $\mathrm{X}_{1}$ (Penguasaan Kosakata) dan $\mathrm{X}_{2}$ (Kemampuan Berpikir Kreatif) terhadap variabel terikat $\mathrm{Y}$ (Kemampuan Menulis Teks Naratif).

Hasil dari analisis regresi diperoleh persamaan garis regresi $\gamma=32,532+$ $0,376 X_{1}+0,251 X_{2}$. Nilai konstanta 32,532 menunjukkan bahwa dengan tingkat penguasaan kosakata dan kemampuan berpikir kreatif paling rendah, sulit bagi siswa mampu menulis teks naratif. Sedangkan nilai koefisien 0,376 dan 0,251 menunjukkan bahwa terdapat pengaruh positif variabel bebas $\mathrm{X}_{1}$ (Penguasaan Kosakata) dan $\mathrm{X}_{2}$ (Kemampuan Berpikir Kreatif) terhadap variabel terikat $\mathrm{Y}$ (Kemampuan Menulis Teks Naratif). Angka koefisien regresi tersebut juga menunjukkan bahwa setiap ada kenaikan satu nilai tingkat penguasaan kosakata maka akan terdapat kenaikan kemampuan menulis teks naratif sebesar 0,376, dan setiap ada kenaikan satu nilai kemampuan berpikir kreatif maka akan terdapat kenaikan kemampuan menulis teks naratif sebesar 0,251.

Setelah dilakukan pengujian linieritas garis regresi dengan menggunakan program SPSS diperoleh bahwa garis regresi tersebut linear. Dari pengujian signifikansi koefisien regresi yang juga dilakukan dengan program SPSS diperoleh bahwa koefisien regresi tersebut signifikan, yang berarti benar bahwa terdapat pengaruh yang signifikan variabel bebas $\mathrm{X}_{1}$ (Penguasaan Kosakata) dan $\mathrm{X}_{2}$ (Kemampuan Berpikir Kreatif) secara bersama-sama terhadap variabel terikat $\mathrm{Y}$ (Kemampuan Menulis Teks Naratif).

Menurut teori penguasaan kosakata pada hakikatnya seorang calon penulis dapat meracik narasinya dengan mengambil arti-arti yang terkandung di dalam kosakata itu. Sebab, makna-makna yang terkandung di dalam kosakata itu relatif cukup banyak, sehingga memungkinkan karangan narasi seseorang menjadi indah 
dan menarik. Berpikir kreatif pada hakikatnya merupakan proses yang digunakan ketika dihasilkannya ide baru, dan ide itu merupakan gabungan dari ide-ide yang sebelumnya belum disatukan.

Dari uraian teoretis tersebut dapat diasumsikan bahwa semakin tinggi tingkat penguasaan kosakata seorang siswa, dan semakin tinggi tingkat kemampuan berpikir kreatif atau dengan kata lain memiliki kreativitas yang tinggi, maka akan semakin tinggi pula kemampuan siswa tersebut dalam menulis jenis teks naratif.

Dari informasi kuantitatif dan teori tersebut peneliti berkesimpulan bahwa tingkat penguasaan kosakata dan kemampuan berpikir kreatif berpengaruh secara bersama-sama terhadap kemampuan menulis teks naratif.

\section{Pengaruh Penguasaan Kosakata $\left(X_{1}\right)$ terhadap Kemampuan Menulis Teks Naratif Bahasa Indonesia $(Y)$}

Dari pengujian hipotesis diperoleh bahwa nilai Sig. $=0.006$ dan thitung $=$ 2,888 sedangkan $\mathrm{t}_{\text {tabel }}=1,684$. Karena nilai Sig. $<0,05$ dan $\mathrm{t}_{\text {hitung }}>\mathrm{t}_{\text {tabel }}$ maka $\mathrm{H}_{0}$ ditolak, yang berarti terdapat pengaruh yang signifikan variabel bebas $\mathrm{X}_{1}$ (Penguasaan Kosakata) terhadap variabel Y (Kemampuan Menulis Teks Naratif).

Menurut teori penguasaan kosakata merupakan salah satu dari komponen yang diperlukan dalam keterampilan berbahasa. Tanpa memiliki penguasaan ini, bahasa yang diucapkan seseorang khawatir tidak diterima oleh orang lain, apalagi oleh orang yang dikategorikan bahasa Indonesia-nya cukup baik.

Penguasaan kosakata yang dimiliki seseorang selain sebagai salah satu keharusan dalam keterampilan berbahasa, juga selalu bersinggungan dengan kemampuan menulis karangan narasi. Tulisan narasi seseorang dapat dianggap baik dan benar, jika kosakatanya dapat diimplementasikan secara beraturan. Sebab, keterampilan menulis karangan narasi, selain hakikatnya adalah kemampuan menyampaikan perasaan, pikiran, dan kehendak kepada orang lain, dengan sejelasjelasnya dalam bentuk cerita pendek, juga bagaimana orang lain, pembaca dapat menilai bahwa kosakata yang dimunculkan dalam narasinya telah terhindar dari kesalahan, meminimalisir kesalahannya.

Dari informasi kuantitatif dan teori tersebut peneliti berkesimpulan bahwa tingkat penguasaan kosakata memiliki pengaruh yang positif dan signifikan terhadap kemampuan menulis teks naratif.

\section{Pengaruh Kemampuan Berpikir Kreatif $\left(X_{2}\right)$ terhadap Kemampuan Menulis Teks Naratif Bahasa Indonesia (Y)}

Berdasarkan hasil analisis data SPSS 20.0 dapat Dari pengujian hipotesis diperoleh bahwa nilai Sig. $=0.098$ dan $t_{\text {hitung }}=1,690$ sedangkan $t_{\text {tabel }}=1,684$. Karena nilai Sig. 0.098>0.05 maka $\mathrm{H}_{0}$ diterima, yang berarti tidak terdapat pengaruh yang signifikan variabel bebas $\mathrm{X}_{2}$ (Kemampuan Berpikir Kreatif) terhadap variabel $\mathrm{Y}$ (Kemampuan Menulis Teks Naratif).

Menurut teori berpikir kreatif merupakan proses yang digunakan ketika dihasilkannya ide baru, dan ide itu merupakan gabungan dari ide-ide yang sebelumnya belum disatukan. Ide seseorang berpikir kreatif minimal mempunyai salah satu karakteristik dari: (a) Ide itu belum ada sebelumnya; (b) sudah ada di tempat lain, hanya saja ia tidak tahu; (c) ia menemukan proses baru untuk 
melakukan sesuatu; (d) ia menerapkan proses yang sudah ada pada area yang berbeda; (e) ia mengembangkan sebuah cara untuk melihat sesuatu pada perspektif yang berbeda. Dari lima karakteristik tersebut, dapat disimpulkan bahwa berpikir kreatif dapat berupa ide baru sebagai penyempurnaan dari yang sudah ada sebelumnya.

Dalam menulis teks naratif, tentunya dituntut untuk memiliki kreativitas dalam menyampaikan cerita, agar cerita dapat disajikan lebih menarik. Bisa jadi menuliskan kembali cerita yang sudah ada, tetapi jika 'kemasannya' lebih menarik, tentu akan lebih meningkatkan minat baca para pembacanya, pesan yang ingin disampaikan pun akan lebih jelas dan sampai kepada pembaca. Namun, siswa juga dapat menulis teks naratif apabila memiliki penguasaan kosakata dengan baik. siswa juga dapat menulis berdasarkan pengalaman. Jadi kreativitas bukan sematamata penentu seseorang mampu menulis teks naratif.

Dari informasi kuantitatif dan teori tersebut peneliti berkesimpulan bahwa tingkat kemampuan berpikir kreatif tidak terlalu mempengaruhi kemampuan seseorang dalam menulis teks naratif. Atau dapat dikatakan, kemampuan berpikir kreatif tidak memiliki pengaruh yang signifikan terhadap kemampuan menulis teks naratif.

\section{SIMPULAN}

Berdasarkan uraian di atas, dapat disimpulkan bahwa terdapat pengaruh yang signifikan penguasaan kosakata dan kemampuan berpikir kreatif secara bersamasama terhadap kemampuan menulis teks naratif siswa SMP Swasta di kota Depok. Hal ini dibuktikan dengan nilai Sig. $=0,000<0,05$ dan $F_{\text {hitung }}=14,852>F_{\text {tabel }}=$ 2,80 . Terdapat pengaruh yang signifikan penguasaan kosakata terhadap kemampuan menulis teks naratif siswa SMP Swasta di kota Depok. Hal ini dibuktikan dengan nilai Sig. $=0,006<0,05$ dan $t_{\text {hitung }}=2,888>t_{\text {tabel }}=1,684$. Tidak terdapat pengaruh yang signifikan kemampuan berpikir kreatif terhadap kemampuan menulis teks naratif siswa SMP Swasta di kota Depok. Hal ini dibuktikan dengan nilai Sig. $=0,098>0,05$ dan $t_{\text {hitung }}=1,690>t_{\text {tabel }}=1,684$.

\section{DAFTAR PUSTAKA}

Alwasilah. (2007). Pokoknya menulis. Jakarta: Rineka Cipta.

Arikunto, S. (2006). Prosedur penelitian suatu pendekatan praktik. Jakarta: Rineka Cipta.

Fahrudin, \& Jamaris, M. (2005). Peningkatan penguasaan kosakata bahasa Inggris melalui permainan, 3(2), $1-41$.

Hartati. T. (2002). Meningkatkan kemampuan berpikir kreatif melalui sastra. JASSI_Anakku. 1 No. 1.UPI. 82

Setiaji, B. (2004). Panduan riset dengan pendekatan kuantitatif. Surakarta: Program Pascasarjana UMS.

Sugiyono. (2002). Metode penelitian administrasi. Bandung: CV Alfabeta.

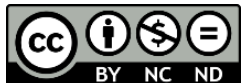

Creative Commons Attribution-NonCommercial-NoDerivatives 4.0 International License 
Diskursus: Jurnal Pendidikan Bahasa Indonesia

Vol. 2, No. 3, Desember 2019, pp. 216-224

p-ISSN: 2615-4935

e-ISSN: 2615-4943

Sugiyono. (2006). Metode penelitian kuantitatif dan kualitatif. Bandung: Alfabeta. Tarigan, H.G (2008). Menulis sebagai suatu keterampilan berbahasa. Bandung: Angkasa 